\title{
Envy in Neoliberalism: \\ Revisiting Veblen's Emulation and Invidious Distinction
}

\author{
Mary V. Wrenn \\ Joan Robinson Research Fellow in Heterodox Economics \\ Girton College \\ University of Cambridge \\ mw561@cam.ac.uk
}

Key words: envy, ontology, neoliberalism, heterodox, individual, Veblen

JEL: B52, N32, ,P1, Z1

\begin{abstract}
:
Cautionary tales admonishing against the evils of envy crowd religion and folklore across cultures. Pre-capitalist societies attempted to suppress envy; familial and community relations held the emotion of envy in check through social sanctions. Capitalism, however, encourages envy.

The connection between capitalism and envy is not new; Veblen methodically addressed it in his explanation of invidious distinction and emulation. As capitalism has evolved into its present incarnation of neoliberalism, however, envy has also evolved. The evolution, nature, and role of envy within neoliberalism must be studied in order to understand more fully its consequences. This research seeks to examine the social ontology of envy. According to advocates of neoliberalism, inequality serves an important social function - it is the great motivator, without which, individuals would not have incentive to improve. Inequality and by extension envy, are thus heralded as the prime catalysts of economic activity.
\end{abstract}

Biographical note:

Mary V. Wrenn is the Joan Robinson Research Fellow in Heterodox Economics at Girton College, University of Cambridge. Mary's research interests include locating ontological concepts such as agency, identity, and emotions within the historical framework of neoliberalism. This paper was presented at the annual meeting of the Association of Evolutionary Economics, January 2015 in Boston.

\section{A (brief) evolution of envy}


The emotional experience of envy ${ }^{1}$ is universal, spanning across time and culture. In precapitalist societies, envy served an evolutionary purpose; the emotion of envy acted as an internal alarm system that notified the individual of critical survival issues. In these societies, envy acted as an emotional warning that alerted the individual that $\mathrm{s} /$ he was performing unfavorably compared to a rival. These early manifestations of envy centered on acquiring the physical needs of life, securing a mate, and health, especially that of offspring (Foster 1972). Natural selection favored the adaptation of envy because it motivated increases in effort in the securing of resources necessary for survival and in reproduction. Once the basic means of survival had been secured for instance, as infant mortality reduced - the envious impulse evolved and new objects of envy emerged (Hill and Buss 2008).

As communities became agrarian and sedentary, the economic surplus consequently grew and it became possible for a community to support non-food producing specialists. Diamond argues that the genetic predisposition to acquire and produce sustenance in the form of food lead to psychological insecurity in those non-food producing specialists, who were no longer contributing to that basic need. It was this insecurity, this particular stage in the evolution of envy, that drove these specialists to try to control the production of the surplus and thus laid the groundwork for what Veblen referred to as "predatory culture” $(2007,19)$.

The work of anthropologists whose research focuses on pre-capitalist economies ${ }^{2}$ shows that everywhere the institutional configuration stressed community needs above those of the individual, cultural mechanisms and social sanctions existed which curtailed the impulse of envy (Stanfield 1982). Pre-capitalist societies engaged in ceremonial expenditure in order to placate the peasantry and quell envy in order to maintain the status quo (Foster 1972). With the evolution of 
envy, cultural institutions as evidenced in artifacts and literature, evolved to dampen the envious impulse, to socially sanction envious behavior, and to protect oneself from the envious gaze. PreChristian traditions featured anthropomorphized manifestations of envy: the Roman goddess Invidia and the Greek goddess Nemesis (Kaster 2005). The Old Testament is filled with cautionary tales against the evils of envy - two such stories feature in the first book of the Bible: the stories of Cain and Abel and of Joseph and the coat - both of which warn of the consequences of sibling rivalry which is driven by envy (Schimmel 2008). Pre-Christian fetishes, such as the nazar and the hamsa, thought to guard against the envious gaze remain popular as charms or amulets (Levy and Zumwalt 2002). The antecedent roots of envy are thus both ancient and ubiquitously evidenced cross-culturally.

The manifestation of envy found in the psychological insecurity of non-food producers intensifies in industrialized, capitalist economies, where the specialization of labor insures that no economic participants are self-sustaining. Within capitalism, accumulation becomes the driving force, for it is the accumulation of wealth and resources that insures the individual's ability to reproduce her standard of living. This drive to accumulate, however, is not a natural, immutable human instinct - it is not hardwired into our DNA. To see that the accumulative drive is culturally constructed, impelled by the forces of capitalism, one needs only to turn to the early economies of hunter-gatherers. These communities were of necessity, nomadic and therefore discouraged accumulation as it hindered mobility. The insatiability of capitalist economies is therefore not the amplification of innate human tendencies, but rather the active cultural encouragement of specific patterns of behavior (Stanfield 1982). 
The link between envy and the drive to accumulate was made clear by Thorstein Veblen in the Theory of the Leisure Class wherein Veblen shines a spotlight on the nature and growth of 'emulation' and 'invidious distinction' as both by-product and impetus of the consumer insatiability of capitalist economies. In industrialized (and post-industrialized) economies, material goods became the artifact, the symbolic representation of status (Foster 1972). This preoccupation with accumulation of the material that is core to the functioning of capitalism prompts Veblen's analysis of the envious impulse within capitalism in both the envy of others as captured in 'emulation' and the attempts to make oneself enviable as described in 'invidious distinction.' Veblen's analysis, however, only explores the benign expression of envy; as will be explored further below, malicious envy reveals much about the nature of this latest stage of capitalism, neoliberalism.

\section{The nature of envy}

Within the fields of social psychology and philosophy exists a long tradition of differentiating between two types of envy: that which is benign versus that which is malicious. The cultural recognition of these two experiences and expressions of envy stretches even further back as evidenced in the evolution of languages which have two separate words for benign and malicious envy, such as Dutch, Polish, and Thai ${ }^{3}$ (van de Ven et al. 2009).

Benign envy is the relatively weak form of envy as it is the negative expression of the emotion of admiration. Devoid of hostility and non-malicious in nature, benign envy could be framed as a compliment to the envied: an appreciation of the envied's success (Miceli and Castelfranci 2007; Smith and Kim 2007). In this "sanitized" version, envy can be considered a motivating force, providing the inspiration for the emulative drive at the level of the individual 
and economic growth at the broader level of society (Smith and Kim 2007, 47; van de Ven 2014). This is not to suggest that benign envy is harmless; indeed the deleterious effects of trying to "keep up with the Jones'" should not be overlooked. Veblen's Theory of the Leisure Class explores at length the pernicious and wasteful side of benign envy.

The darker side of envy is that of malicious envy, wherein the envier does not aspire to reach the same heights as the envied, but rather hopes that demise will befall the envied and bring her down to the same level, or preferably a level below the envier. Malicious envy is more closely related to the emotion of resentment and contains an element of hostility that is directed at the envied, even when the envied has not acted against the envier. In malicious envy, the envier falls short in comparing herself to the envied, which provokes feelings of inferiority and impotence in overcoming the perceived inferiority. The hostility felt toward the envied might transform into aggressive ill-wishing or action, even when there is no pay-out for the envier. As such, malicious envy is not strategic or goal-oriented; the only objective is to find some relief from the envier's feelings of inferiority (Miceli and Castelfranci 2007).

Whether a given envier experiences benign or malicious envy depends on a number of quotidian factors that impact the psychological state of the envier, such as general mood or how the envier discovers the envied's success in possession or achievement of the object of desire. Likewise, the envier's recent experiences color the manner in which that news is processed; individuals with recently experienced set-backs or disappointments have a tendency to react more negatively than $\mathrm{s} /$ he might otherwise have reacted. Reminders of other recent failures or shortcomings can amplify an already negative mood (Alicke and Zell 2008). 
Because envy runs counter to social norms, and because admitting to envy often means admitting to inferiority or lack, individuals will often deny feelings of envy. To envy someone simply because they possess something that the envier does not, as opposed to having actively done something detestable to the envier, means that the envier is harboring negative sentiment toward someone who has done nothing to him/her, perhaps even someone without a relationship with the envier. This harboring of ill-will inflicts further damage to the already bruised self-esteem of the envier, given the pettiness of its origins (Smith 2013).

Individuals, unable to cope with the shame of having failed or fallen short, can seek refuge in rationalization. Specifically, by feeding a perception of an external locus of control, an envier is able to explain his/her lack and the envied's gain that is logically consistent within the envier's own frame of reference. Such rationalization fuels anger and hostility at the perceived advantage of the envied and the injustice therein. Rationalizations might be composed of any number of explanations or combinations of explanations for the envied's success: a pre-existing advantage, gains were achieved through illegitimate or fraudulent means, or unearned advantage, say by virtue of birth or physical standing. Attempts to undermine or discredit the envied fuel the sense of injustice created by the envier's relative lack. Given an accumulation of rationalizations, externalization of responsibility, and ad hominem attacks, the sense of injustice is fed and expands creating a self-sustaining cycle of malicious envy which can morph into outright hostility, and given enough fuel, turn into schadenfreude (Sundie et al. 2009; Miceli and Castelfranci 2007).

Schadenfreude is a German word that literally translated is the combination of "harm" and "joy" and describes the elation an individual feels at witnessing the misfortune of others. Schadenfreude is a subset of malicious envy, although envy is a necessary but not sufficient cause of 
schadenfreude (Smith 2013; van Dijk et al. 2005). The antecedent to schadenfreude is malicious envy, seeded by a sense of injustice resulting from the perception of the unfair advantage possessed by the envied and nurtured by initial dislike and mounting anger (Sundie et al. 2009).

Another more active manifestation of malicious envy is that of sabotage. Acts of sabotage motivated by malicious envy tend to manifest in subtle ways such as undermining of the efforts of a co-worker or spreading gossip about a social rival (Chen 2003). This "social undermining behavior" is aimed toward chipping away at the envied's reputation, disrupting the envied's relationships, and causing the envied's performance either socially, at work, or both, to slip (Duffy et al. 2008, 177).

\section{Neoliberalism and envy}

Neoliberalism embodies the ideological shift in the purpose of the state from one that has a responsibility to insure full employment and protect its citizens against the exigencies of the market to one that has a responsibility to insure individual responsibility and protection of the market itself (Harvey 2005). The neoliberal narrative consists of a central ideological construct hyper-individualism - whereby the locus of control is the individual exercising agency through (free) market operations. This simple ideological construct not only marks a shift in focus from the community to the individual, but it also denies the essential social nature of humans. Hyperindividualism, which only acknowledges individual action and individual responsibility, provides the core justification for neoliberalism.

The trope of individual responsibility teaches that those who are in some way disadvantaged or have failed within the market system deserved to do so - it is the fault of the poor that they are poor, and further, it is the fault of the poor that they stay that way. The rich, 
likewise, deserve what they have, regardless of how their wealth might have been acquired (Jost et al. 2003). Under the enabling myth of equality of opportunity, all individuals, regardless of beginnings or background, are responsible for their own success or failure. In this bootstrap society, inferiority is earned through lack of effort and unwillingness to work. It seems reasonable to suggest that resentment and malicious envy is more likely within neoliberalism where personal responsibility is such a critical component and where individual inferiority is highlighted rather than possible systemic failures or injustices.

According to the neoliberal narrative, an individual's place in the financial hierarchy is the key indicator of success (Wrenn 2014). This means that not only is an individual's ontological security determined by her performance within the market place, but her success in life as well. Success that is measured by non-financial means, such as work that is fulfilling, rewarding in its own right, or based on intangible markers is irrelevant according to the neoliberal rubric. Within neoliberalism, unless success is financially rewarded, it is devalued. Researchers have found that envy is particularly prevalent in societies with inequality, especially where that inequality is visible through the power and possessions of the "haves" (Foster 1972). This would seem to suggest that the growing inequality gap that has come to characterize neoliberal economies and which not only widens, but distances individuals in terms of observable qualities, could lead to even greater disillusionment and turn emulative-driven, benign envy into malicious envy.

Furthermore, anthropologists have found that the perception of economic or social mobility also encourages envy. Individuals living within a caste system were found to experience less envy as the well-defined borders and socio-economic immobility provided stability, order, and an accepted explanation for the individual's place in society (Foster 1972). While the 
"encapsulated social units" of modern capitalism are well-defined with physical and visible boundaries, such as urban ghettos, country clubs, and gated communities (Foster 1972, 185), the perception of permeable borders persists. Individuals who are able to progress out of poverty are particular targets of envy as those individuals have upset the social order. This popular, neoliberal trope of socio-economic mobility coupled with the occasional, exceptional success story catalyzes frustration, and the benign envy that might have once been aspirational can sour into resentment and malicious envy.

Mainstream economics, in defining the purpose of the economics discipline as the study of the allocation of scarce resources among competing wants, promotes the idea that the central problem in all economies is that of scarce resources. Framing the question of allocation as an individually driven scramble to secure enough for oneself instead of as a potentially collective decision process aimed toward the flourishing of everyone, further fuels the competitive impulse of neoliberalism. Moreover, this artificial scarcity amplifies envy. Since envy emerges from competitive behavior (Miceli and Castelfranci 2007), it stands to reason that as neoliberalism and the competitive impulse that characterizes it intensifies, so too is the emotion of envy amplified.

Advertising offers perhaps the clearest example of deliberate evocation of envy within capitalism writ large. To be sure, the nature of advertisements and advertising methods have changed over time, but whether the adverts employ informational or esoteric content, the message remains the same - you, the consumer lack something possessed by others; advertising unfailing plays on the emotion of envy. Luckily, for the consumer, advertising also proffers a solution with the purchase of the product or service you can obtain the remedy for what you lack. Advertising thus presents the problem of relative deprivation or lack and offers the solution of 
possession through consumption, all through the mechanism of envy (Foster 1972, van de Ven 2009).

\section{Concluding remarks}

Social organization, more than individual personalities or psychologies, drive the overall predisposition of a community either away or toward self-interested or community-minded behavior. As such, scarcity is not the universal driver of economic behavior, but rather the institutional configuration which defines both scarcity and the reaction of community members to it that ultimately define economic relationships and the broader economic system. This is not to say that institutions are the sole driver of behavior - there exists a genuine interactivity between individuals and institutions, each of which impact one another and evolve independently as the result of internal development. Noting the influence of institutions is merely a way to highlight the central premise that economic behavior emerges from repeated patterns of interaction which are encapsulated in the surrounding institutional context (Stanfield 1982).

Researchers suggest that envy is an upward comparison more so than a comparison between objectively similar individuals. While this upward comparison might serve positive ends, encouraging self-improvement, providing motivation, or goal-orientated action, if those differences are rooted in the path-dependent advantages enjoyed by the envied, then the upward comparison will lead to disappointment and depression (Miceli and Castelfranci 2007).

Veblen's analysis of benign envy in turn-of-the-century capitalism highlights by way of contrast the growth of malicious envy within neoliberalism. It seems only logical that within neoliberalism, which venerates individual responsibility and competitiveness, and features a high degree of income inequality, unequal access to social mobility, and a super-saturated landscape of 
conspicuous consumption that envy, particularly malicious envy, is all the more relevant. Given that envy is a human impulse which can be either reinforced, amplified, or dampened by the surrounding institutional milieu, then social scientists should be held responsible for examining and suggesting policy changes which can address and attempt to redirect the way in which its individuals experience any given emotion, but especially that of envy. Malicious envy is unhealthy, and if neoliberalism as an economic system promotes or encourages malicious envy, then we must see neoliberalism as a toxic institution and seek institutional changes to address it as such. 


\section{Notes}

1. There are many arguments surrounding the demarcation between the emotions of envy and jealousy. Instead of becoming entangled between what are certainly important differences, this research will focus on envy as the emotion experienced when the envier does not possess something s/he wants and jealousy as the emotion experienced as fear of loss of something already possessed.

2. See in particular: Sahlins 1972, Thomas 1959, Hogbin 1951, and Firth 1950.

3. The words for "benign envy" and "malicious envy" are (respectively) as follows: Dutch: "benijden and afgunst;" Polish: "zazdrosc and zawisc;" Thai (spelled phonetically): "it-chaea and rit-yaa" (van de Ven et al. 2009, 420).

\section{Reference List}

Alicke, Mark D. and Ethan Zell. "Social Comparison and Envy" in Envy: Theory and Research, edited by Richard H. Smith, pp. 73-93. Oxford: Oxford University Press, 2008. Chen, Kong-Pin. "Sabotage in Promotion Tournaments." Journal of Law, Economics, and Organization 19, 1 (2003): 119-140.

Diamond, S. In Search of the Primitive. New Brunswick, NJ: Transaction Press, 1974.

Duffy, Michelle K., Jason D. Shaw, and John M. Schaubroeck. "Envy in Organizational Life" in Envy: Theory and Research, edited by Richard H. Smith, pp. 167-189. Oxford: Oxford University Press, 2008.

Firth, Raymond. Elements of Social Organization. London: Watts and Co, 1963.

Foster, George M. "The Anatomy of Envy: a Study in Symbolic Behavior." Current 
Anthropology 13, 2 (1972): 165-202.

Harvey, David. A Brief History of Neoliberalism. Oxford: Oxford University Press, 2005.

Hill, Sarah E. and David M. Buss. "The Evolutionary Psychology of Envy" in Envy: Theory and Research, edited by Richard H. Smith, pp. 60-70. Oxford: Oxford University Press, 2008.

Hogbin, H. Ian. Transformation Scene: The Changing Culture of a New Guinea Village. London: Routledge and Kegan Paul, 1951.

Jost, John, Sally Blount, Jeffrey Pfeffer, and Gyorgy Hunyadi. "Fair Market Ideology: Its Cognitive-Motivational Underpinnings." Research in Organizational Behavior 25, 3 (2003): $53-91$.

Kaster, Robert A. Emotion, Restraint, and Community in Ancient Rome. Oxford: Oxford University Press, 2005.

Levy, Isaac Jack and Rosemary Levy Zumwalt. Ritual Medial Lore of Sephardic Women: Sweetening the Spirits, Healing the Sick. Illinois: University of Illinois Press, 2002.

Miceli, Maria and Cristiano Castelfranchi. "The Envious Mind." Cognition and Emotion 21, 3 (2007): 449-479.

Sahlins, M. Stone Age Economics. Chicago: Aldine Publishing Co, 1972.

Schimmel, Solomon. "Envy in Jewish Thought and Literature" in Envy: Theory and Research, edited by Richard H. Smith, pp. 17-38. Oxford: Oxford University Press, 2008.

Smith, Richard H. The Joy of Pain: Schadenfreude and the Dark Side of Human Nature. Oxford: Oxford University Press, 2013. 
Smith, Richard H. and Sung Hee Kim. "Comprehending Envy." Psychological Bulletin 133, 1 (2007): 46-64.

Stanfield, J. R. "Learning From Primitive Economies." Journal of Economic Issues 16, 2 (1982):471479.

Sundie, Jill M, James C. Ward, Daniel J. Beal, Wynne W. Chinn, and Stephanie Geiger-Oneto. "Schadenfreude as a Consumption-related Emotion: Feeling Happiness about the Downfall of Another's Product.” Journal of Consumer Psychology 19 (2009): 356-373.

Thomas, Elizabeth M. The Harmless People. New York: Knopf, 1959.

van de Ven, Niels, Marcel Zeelenberg, and Rik Pieters. "Leveling Up and Down: The Experiences of Benign and Malicious Envy.” Emotion 9, 3 (2009): 419-429.

van de Ven, Niels. "Malicious Envy and Schadenfreude" in Schadenfreude: Understanding Pleasure at the Misfortune of Others, edited by Wilco W. van Dijk and Japp W. Ouwerkerk, pp. 110-117. Cambridge: Cambridge University Press, 2014.

van Dijk, Wilco, Jaap Ouwerkerk, Sjoerd Goslinga, and Myrke Nieweg. “Deservingness and Schadenfreude." Cognition and Emotion 19, 6 (2005): 933-939.

Veblen, Thorstein. The Theory of the Leisure Class. Oxford: Oxford University Press, 2007. Wrenn, Mary V. "Identity, Identity Politics, and Neoliberalism.” Panoeconomicus 4 (2014): 503515. 